\title{
Reading Habits Of Business Students
}

\author{
Kay H. Braguglia, (E-mail: kay.braguglia@hamptonu.edu), Hampton University
}

\begin{abstract}
What are the reading habits of college students? This paper reports the results of a survey of undergraduate business students addressing this question. The objectives were to determine: (1) what business publications students read and how often they read them, (2) what students read for pleasure and how often, (3) how many hours a week students spend in various activities including reading, and (4) what activities interfere most with reading and study. The results indicate that college textbooks are the most frequently read business material with 42 percent reading textbooks daily. Business related material on the internet was read by 17 percent of the students on a daily basis. For pleasure, students read magazines, religious publications, and newspapers the most often. Students tend to read these publications at least once a week. Novels, nonfiction, fiction, poetry, and comic books were read on a weekly basis by less than one half of the students. The results indicate that many students are not reading on a daily basis whether it is business related or for pleasure.
\end{abstract}

If students are not reading, what are they doing? Students spend time watching television (31 percent watch 12 or more hours per week), talking on the telephone (27 percent talk on the phone 12 or more hours per week), and listening to recorded music (23 percent listen 12 or more hours per week). Students report spending fewer hours reading with 3 percent indicating that they spend 12 or more hours reading each week. When asked whether work, sports, clubs/organizations, personal relationships, or child care interfered with reading and study, the students responded that personal relationships as well as clubs and organizations interfered more often with reading and studying.

\section{INTRODUCTION}

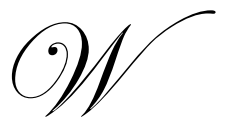

hat are the reading habits of college students? This paper reports the results of a survey of undergraduate business students addressing this question. The objectives were to determine: (1) what business publications students read and how often they read them, (2) what students read for pleasure and how often, (3) how many hours a week students spend in various activities including reading, and (4) what activities interfere most with reading and study. The study focuses on the time students spend reading and provides insight on college reading habits.

\section{STUDENT READING HABITS}

Research has treaded softly around issues of reading for college students. A large amount of research on college readers has not been conducted. However, much research has been collected on college students' recollections of early reading experiences (Fowler, 2003). Studies that have been made show that college student's inadequate reading and study skills have existed since the $19^{\text {th }}$ century, not only in public universities, but also in the nation's most prestigious institutions (Bichy, 2003). Over seventy-five years ago, Jenkins lumped readers into three categories: the sponge reader who absorbs material, the sieve reader who reads best sellers, and the duck-back reader who reads newspapers and magazines to keep busy (1928). During the 1970s and 1980s, studies indicated that reading rates dropped (Kingston, 1986). The familiar refrain was, this generation does not read. They are strangers to points of reference and underlying cadences that govern the development of written English. They cannot write because they do not read (Atlas, 1990, 97). In a survey designed to observe the actual study habits of college students, it was determined that even students who were succeeding at a highly competitive major university benefited from efficient study strategies. When average and advanced students enter college from high school, they 
encounter learning contexts previously unknown to them, and for which they have no experience or training (Bichy, 2003).

Professors make assumptions about students' reading habits before coming to decisions about their reading requirements for a particular course or topic. These assumptions relate to the speed and efficacy of reading together with the recognition and appreciation of the significance of materials to be read. College students are expected be efficient and proficient readers. Many college courses require students to read 100-150 pages of material per week. When this is multiplied by 4 or 5 courses per semester it equates to 400 or more pages per week. Time management is crucial to keeping up on reading assignments. Students must have good organization skills for college. If they are disorganized, they will quickly find themselves falling behind in assignments, due dates and reading (Glencoe, 2004).

A common observation among college instructors is that their students do not seem particularly motivated to read the assigned readings, especially on a regular basis. Students come to class unprepared and worse yet many save the readings until the night before the exam. This problem is universal enough that it tends to be a source of irritation and frustration for many college professors (Instructional Consulting, 2002). Many college students today are not strong readers; they regularly report that they don't like to read. If their peers report reading in a given course isn't all that essential, students are only too ready to read half-heartedly or not at all. In fact, students and faculty may have different opinions as to the value and necessity of reading textbooks. In one eight year old study, 55 percent of the faculty considered textbooks very important compared to 49 percent of college students (Pringle, 1996). If students see textbooks as less important for success in courses than their professors do, this assumption about the value of the textbook can translate into lax reading habits. The bottom line is that a significant number of students show up for class not having done the reading and are therefore not fully prepared to participate in class activities that presume knowledge of textbook content. Unfortunately, it's a bottom line many professors have experienced, and one that many have come to accept.

Nevertheless, 86 percent of college courses require a textbook, 26 percent require some material in electronic format, and 36 percent require a course pack, reader or customized material. The percentage of college courses that require a textbook has dropped 8 percent since 1999 when 94 percent required a textbook and 9 percent since 1998 when 95 percent required a textbook. However, a required textbook is not a guarantee that a textbook will be purchased. Students purchase 85 percent of their required texts, down from 91 percent in 1999 and 94 percent in 1998. Just over half (55 percent) purchase all of their required course material (National Association of College Stores, 2004). The trend toward not purchasing materials is a concern when 72 percent of college courses use textbooks in reading assignments, and 70 percent base examinations on information found in textbooks (National Association of College Stores, 2002). Students complain about the prices and try to get through the semester without buying books. Textbook prices have gone up 26 percent since 2000 and 56 percent in the last decade. However, as a group, students pay more for their cell phone calls than for textbooks (Rosenberg, 2004).

Reading is essential to academic success and to intellectual growth. The National Endowment for the Arts (NEA) surveyed 17,000 individuals and discovered that in 198257 percent of adult Americans read literature and in 2004 the figure has fallen to 46.7 percent. The rate of decline for the youngest adults, those aged 18 to 24 , was 55 percent greater than that of the total adult population. The NEA study did not include nonfiction or college student reading, however, it is believed that decline of reading threatens not only America's arts heritage but its economic position in the world as well. Reading requires sustained focused attention, working with the powers of memory and imagination. Economic success depends on innovation and creativity which comes from reading. Television, video games, and even the internet are more passive than reading. Reading forces the reader to think; watching allows escape. College students nowadays do not have the traditional sense of the role that reading plays in the development of one's life (NEA, 2004).

Many believe that recreational reading or reading for pleasure has a relationship with academic success. Reading is the cornerstone for success, not just in school but throughout life. A study conducted in 1999 looked for evidence to support this assumption and found a significant correlation between recreational reading and cumulative grade point average. The study found that 63 percent of the students spent less that two hours per week reading for 
pleasure, but did not find differences between males and females or student classification. Seniors did not spend more time reading for pleasure than first year students. Therefore, it was concluded that reading habits are already well established by the time students enters college. So the experience of being in college does not influence how much time will be spent on reading recreationally. In fact, recreational reading habits are acquired early in an individuals' school life, probably in elementary school. Considering what college students read for recreation, 75 percent read magazines, 65 percent read letters, e-mails and chat room correspondence, 54 percent read newspapers, 46 percent read novels, 20 read nonfiction, and 1 percent read comic books frequently (Gallik, 1999).

According to a survey to determine internet use, 95 percent of college students use the internet at least once a week. A total of 22.5 percent indicate that they believe that the internet is the most effective way to reach a college students The survey results also found that 70 percent of the students surveyed said that search engines are their primary method of doing research online (Shay, 2000). Undergraduate students on the average send $3.6 \mathrm{e}-$ mails and receive 10.5 e-mails daily (Noll, 2001). Students spend far less time on the Internet than watching television or listening to the radio but they spend more time on the Internet than reading magazines and newspapers (Hintze \& Lehnus 1998).

One explanation as to why students do not spend time reading is that they have too many additional responsibilities that prevent them from spending this time. Research has found the opposite to be true. Students have tremendous leeway in their leisure activities, and do have sufficient time available to study. However, students are choosing not to spend the time reading or studying (Cerrito \& Levi, 1999). Various activities take up students' time.

Like the computer and beeper before it, the cell phone has trickled down through the hierarchy of the professional world from doctor and executives to everyday office and finally to the youth and students of America. While walking to class you can always find someone attempting to dial his or her friend's number. Professors include mobile phone etiquette and rules on syllabi. The saturation of mobile phones has changed the culture of college life and the classroom (Gunter, 2001). Telephone usage (wired or Wireless) by students averaged nearly an hour per day. In fact, telephone traffic is greater than data traffic over the internet (Noll, 2001).

Undergraduate students watch 2.0 hours of television, 1.5 hours of videos, listen to 1.2 hours of radio, and almost 1 hour of music each day. The total time spent watching and listening to entertainment for undergraduate students is 5.4 hours per day (Noll, 2001). Hintze \& Lehnus found similar results in their study, on a particular day 83 to 89 percent watch television or listen to the radio. Those who watch television or listen to the radio spend 2 hours or more doing so. In contrast, those who read magazines or newspapers spend, on the average, less than an hour doing so (Hintze \& Lehnus, 1998). Undergraduate students read newspapers for 21.1 minutes, magazines 16.7 minutes, and books 81.2 minutes per day. The total print usage for undergraduates is 119.1 minutes (Noll, 2001). This is about 2 hours spent in all print media including recreational and college course preparation.

\section{THE STUDY}

Undergraduate students in the School of Business were surveyed in the spring semester of 2004. The school has an enrollment of 1,150 full time undergraduate students in eight areas including accounting, business administration, economics, entrepreneurship, management, marketing, and finance. A sample of 142 of the students participated in this research. Eighty one were female and 61 were male. The typical student is of traditional college age. In this study 75 were under 20 years, 65 were $21-24$, and 2 were over 24 . The study included 30 freshman, 20 sophomores, 40 juniors, and 52 seniors. Cluster sampling was used to identify participants. All courses offered during the spring semester 2004 were listed and from this list a random selection of 10 courses was made. The selection included accounting, business administration, entrepreneurship, economics, marketing, management, and finance courses.

A questionnaire was developed for this study. Completion of the questionnaire required about ten minutes and employed a self-reporting, paper and pencil format. Questionnaires were given to all the participants during a class period. They were briefly informed about the research project and were assured that their responses would 
remain anonymous and confidential. The surveys were given out and collected back at the beginning or end to the class period. A total of 142 questionnaires were completed by business majors. Twelve questionnaires completed by non-business majors were disregarded. Each questionnaire was tallied and categorized. The data were summarized and percentages were calculated.

\section{Survey Results}

College textbooks were read more often than other business material. Textbooks were read daily by 42 percent of the students and weekly by an additional 42 percent. The percentage of students reading textbooks monthly or less was 16 percent. Reading business related material on the internet was second in frequency with 17 percent reading on the internet daily and 44 percent reading weekly. Over 40 percent of the students read business journals, business newspapers, and business magazines on a monthly basis. However, some students never read various types of business materials 1 percent never read a textbook, 20 percent never read business journals, 15 percent never read business newspapers, 9 percent never read business magazines, and 6 percent never read business related materials on the internet.

Table 1: Percentage of Students Reading Business Materials

\begin{tabular}{|l|c|c|c|c|c|}
\hline \multicolumn{1}{|c}{ Item } & $\begin{array}{c}\text { Frequently } \\
\text { Daily }\end{array}$ & $\begin{array}{c}\text { Often } \\
\text { Weekly }\end{array}$ & $\begin{array}{c}\text { Sometimes } \\
\text { Monthly }\end{array}$ & $\begin{array}{c}\text { Rarely } \\
\text { Yearly }\end{array}$ & Never \\
\hline College textbooks & 42 & 42 & 14 & 1 & 1 \\
\hline Business Journals & 1 & 13 & 44 & 21 & 20 \\
\hline Business Newspapers & 4 & 16 & 42 & 22 & 15 \\
\hline Business Magazines & 6 & 18 & 49 & 18 & 9 \\
\hline Business Related on Internet & 17 & 44 & 25 & 8 & 6 \\
\hline
\end{tabular}

Note: Tabled values are percentages and may not equal 100 due to rounding

For recreational reading, 25 percent read magazines daily, 22 percent read internet publications daily, 20 percent read religious publications daily, and 18 percent read newspapers daily. Novels, nonfiction, fiction, poetry, and comic books were read on a daily or weekly basis by less than one half of the students. In fact, 57 percent read poetry yearly or never, 49 percent read novels yearly or never, 62 percent read nonfiction yearly or never, and 48 percent read fiction yearly or never.

Table 2: Percentage of Students Reading For Pleasure

\begin{tabular}{|l|c|c|c|c|c|}
\hline Item & $\begin{array}{c}\text { Frequently } \\
\text { Daily }\end{array}$ & $\begin{array}{c}\text { Often } \\
\text { Weekly }\end{array}$ & $\begin{array}{c}\text { Sometimes } \\
\text { Monthly }\end{array}$ & $\begin{array}{c}\text { Rarely } \\
\text { Yearly }\end{array}$ & Never \\
\hline Newspapers & 18 & 44 & 28 & 8 & 2 \\
\hline Magazines & 25 & 56 & 15 & 4 & 1 \\
\hline Comic Books & 1 & 4 & 4 & 23 & 97 \\
\hline Poetry & 4 & 13 & 25 & 32 & 25 \\
\hline Internet Publications & 22 & 38 & 23 & 10 & 8 \\
\hline Novels & 4 & 14 & 34 & 32 & 17 \\
\hline Nonfiction & 5 & 11 & 23 & 39 & 23 \\
\hline Religious Publications & 20 & 24 & 30 & 16 & 9 \\
\hline Fiction & 4 & 14 & 35 & 32 & 16 \\
\hline
\end{tabular}

Note: Tabled values are percentages and may not equal 100 due to rounding

When students were asked how many hours per week that they spend on various activities the data show that students spend more time watching television, talking on the telephone, listening to music, surfing the internet, participating in sports, or working than on reading. Only watching home movies and video games were lower than reading in the number of hours spent. A total of 32 percent watch television for more than 12 hours per week, 27 percent talk on the telephone more than 12 hours per week, 23 percent listen to recorded music more than 12 hours 
per week, and 15 percent listen to the radio more than 12 hours per week. This compares to only 3 percent indicating that they read more than 12 hours per week. Even considering that some of the activities are used as background while other tasks are being done, 85 percent of the students report reading from either 0-3 or 4-7 hours weekly.

Table 3: Weekly Hours Students Spend on Various Activities

\begin{tabular}{|l|c|c|c|c|}
\hline Item & $\mathbf{0 - 3}$ & $\mathbf{4 - 7}$ & $\mathbf{8 - 1 1}$ & $\mathbf{1 2}$ or More \\
\hline Talk on phone & 15 & 38 & 19 & 27 \\
\hline Watch TV & 14 & 35 & 19 & 32 \\
\hline Listen to Radio & 44 & 25 & 15 & 15 \\
\hline Play Video Games & 76 & 14 & 6 & 4 \\
\hline Watch home Movies & 59 & 31 & 7 & 3 \\
\hline Read & 39 & 46 & 12 & 3 \\
\hline Listen to Recorded Music & 21 & 39 & 17 & 23 \\
\hline Surf the Internet & 27 & 35 & 19 & 18 \\
\hline
\end{tabular}

Note: Tabled values are percentages and may not equal 100 due to rounding

When activities that interfere with reading and study are considered, 26 percent of the students indicated personal relationships interfere often and an additional 33 percent indicated that personal relationships interfere sometimes with reading and study. Twenty-nine percent indicated clubs and organizations sometimes interfere with reading and study. Child care, sports, and work never interfere for more that one half of the students. Less than 10 percent of the students recorded that work, sports, clubs and organizations, personal relationships or child care always interfered.

Table 4: Activities that Interfere with Reading and Studying

\begin{tabular}{|l|c|c|c|c|c|}
\hline Item & Always & Often & Sometimes & Seldom & Never \\
\hline Work & 4 & 10 & 13 & 14 & 59 \\
\hline Sports & 5 & 5 & 13 & 15 & 61 \\
\hline Clubs/Organizations & 5 & 7 & 29 & 27 & 32 \\
\hline Personal Relationships & 8 & 26 & 33 & 18 & 15 \\
\hline Child Care & 0 & 0 & 2 & 5 & 93 \\
\hline
\end{tabular}

Note: Tabled values are percentages and may not equal 100 due to rounding

\section{Summary of Reading Habits}

The results show that 84 percent of the students read college textbooks and 61 percent read business related publications on the internet at least once a week. However, 16 percent read textbooks and 39 percent read business related publications monthly or less. Over 40 percent of the students read business journals, newspapers and magazines weekly. For pleasure students read magazines, newspapers, internet publications, and religious readings, most often. Less than 20 percent read novels, fiction, nonfiction, poetry, or comic books daily or weekly. Almost one half rarely (at least once a year) read novels, fiction, nonfiction, poetry and comic books. During recreational time, the majority of the students spent 0-3 hours a week listening to radio, playing video games, and watching home movies. The largest percentage spent 4-7 hours a week talking on the phone, watching the TV, listening to recorded music, surfing the internet and reading. The students overall responded that personal relationships most often interfered with their reading and studying.

A total of 85 percent of the students report reading from either 0-3 or 4-7 hours weekly. If students are not reading, what are they doing? Students spend time watching television (31 percent watch 12 or more hours per week), talking on the telephone ( 27 percent talk on the phone 12 or more hours per week) and listening to recorded music (23 percent listen 12 or more hours per week). Students report spending fewer hours reading with 3 percent 
indicating that they spend 12 or more hours reading each week. This survey indicates that many students do not spend time reading either for classes or recreation.

\section{REFERENCES}

1. Atlas, J. (1990). Battle Of The Books: The Curriculum Debate In America. New York: W.W. Norton \& Co.

2. Bichy, C. L., (2003). "Reading and study skills", Retrieved on November 7, 2004, from University of Maryland Baltimore Campus Web Site: http://www.umbc.edu/sss/reading skills.html

3. Cerrito, P. \& Levi, I., (1999, December). "An investigation of student habits in mathematics courses". College Student Journal. Retrieved October 21, 2004 from http://static.highbeam.com/c/ collegestudentjounal/december011999/anivestigation

4. $\quad$ Fowler, R. (2003). "The implications of reading preferences of future educators", College Student Journal. Retrieved October 22, 2004 from http://www.find articles.com/plarticles.mi_ooksmart.com/

5. $\quad$ Gallik, J., (March 1999). Journal of Adolescent and Adult Literacy. (9) 480.

6. Glencoe/McGraw-Hill, (2004). "Study tips beyond high school", Teaching tips of the week.

7. Retrieved Oct 21, 2004 from http://www.glencoe.com/sec/teachingtoday/weeklytips.phtml/197

8. Gunter, G., (2001, September). "Is student cell phone usage completely out of control?" Focus. September 28, Retrieved October 22, 2004 from http://cyberbuzz.gatech.edu/technique/issues/fall2001/2001-0928/17.html

9. Hintze, W. \& Lehnus J., (1998) "Media habits and internet usage among America's youth". AB-103 Symposium. Retrieved October 22, 2004 from http://www.internationalmta.org/1998/9813d.html

10. Instructional Consulting, (2002). "What to do when Students do not Read?" Retrieved November 8, 2004 from http://www.indiana.edu/ icy/noread.html

11. Jenkins, M. (1928). "The reading public". In G.C. Clancy (Ed.), Thought and expression: A course in thinking and writing for college students. (20-24), New York: Harcourt, Brace.

12. Kingston, P. (1986). "Teachers and books in the 1980's". In Baker (ed.) Student reading needs in higher education (107-179). London: Library Association

13. National Association of College Stores. (2004, January 21) "Course materials \& purchase factors". Collegiate Market Watch: Research for College Retailers, 131. Retrieved November 17, 2004 from http://www.nacs.org/members/secure/research/marketwatch/131/asp

14. National Association of College Stores. (2002, August 5) "Textbooks: perceptions and reality" Collegiate Market Watch: Research for College Retailers, 121. Retrieved November 17, 2004 from http://www.nacs.org/members/secure/research/marketwatch/121/asp

15. National Endowment for the Arts (2004) Reading at Risk. Retrieved November 16, 2004 from http://www.hea.govf/news04/ReadingatRisk.html

16. Noll, A.M., (2001). Voice vs. data: Estimates of media usage and network traffic. Retrieved October 25, 2004 from http:/www.arxiv.org/pdf/cs.cy/0109007

17. Pringle, T., (1996). And the assigned reading is: students, faculty rate texts. The Daily Cougar. Retrieved November 17, 2004 from http://www.stp.uh.edu/vol62/66/Campus/camp2/camp2.html.

18. Rosenberg, P. (2004, Monday October 11) "Books cost big bucks". Daily Press, Newport News, VA

19. Shay. M. (2000). Prospective graduate students internet and media habits.

20. "The Educational Directories Unlimited". Retrieved on November 8, 2004, from http://www.edudirectories.com/press/press18.html 